University of Nebraska - Lincoln

DigitalCommons@University of Nebraska - Lincoln

Agronomy \& Horticulture -- Faculty Publications

Agronomy and Horticulture Department

$2-2021$

\title{
Corn residue baling and grazing impacts on corn yield under irrigated conservation tillage systems
}

Sabrina J. Ruis

Charles Burr

Humberto Blanco-Canqui

Brian Olson

Mark Reiman

See next page for additional authors

Follow this and additional works at: https://digitalcommons.unl.edu/agronomyfacpub

Part of the Agricultural Science Commons, Agriculture Commons, Agronomy and Crop Sciences Commons, Botany Commons, Horticulture Commons, Other Plant Sciences Commons, and the Plant Biology Commons

This Article is brought to you for free and open access by the Agronomy and Horticulture Department at DigitalCommons@University of Nebraska - Lincoln. It has been accepted for inclusion in Agronomy \& Horticulture -Faculty Publications by an authorized administrator of DigitalCommons@University of Nebraska - Lincoln. 


\section{Authors}

Sabrina J. Ruis, Charles Burr, Humberto Blanco-Canqui, Brian Olson, Mark Reiman, Daran Rudnick, Johnna Baller, and Kathryn J. Hanford 


\title{
Corn residue baling and grazing impacts on corn yield under irrigated conservation tillage systems
}

\author{
Sabrina J. Ruis, ${ }^{1}$ Charles Burr, ${ }^{2}$ Humberto Blanco-Canqui, ${ }^{1}$ \\ Brian Olson, ${ }^{3}$ Mark Reiman, ${ }^{3}$ Daran Rudnick, ${ }^{4}$ \\ Johnna Baller, ${ }^{5}$ \& Kathryn Hanford ${ }^{6}$
}

1 Department of Agronomy and Horticulture, University of Nebraska-Lincoln, Lincoln, NE 68583, USA

2 West Central Research and Extension Center, University of Nebraska-Lincoln, North Platte, NE 69101, USA

3 Bayer Crop Science, Water Utilization Learning Center, Gothenburg, NE 69138, USA

4 Department of Biological Systems Engineering, University of Nebraska-Lincoln, Lincoln, NE 68583, USA

5 Department of Animal Science, University of Nebraska-Lincoln, Lincoln, NE 68583, USA

6 Department of Statistics, University of Nebraska-Lincoln, Lincoln, NE 68583, USA

Correspondence - Sabrina J. Ruis, Department of Agronomy and Horticulture, University of Nebraska-Lincoln, Lincoln, NE 68583, USA Email: sruis2@unl.edu

Published in Agronomy Journal. 2021, 11pp.

DOI: $10.1002 /$ agj2.20642

Copyright (c) 2021 by the authors. Agronomy Journal (c) 2021 American Society of Agronomy. Published by John Wiley \& Sons. Used by permission.

Submitted 18 November 2020; accepted 19 February 2021; published 26 February 2021.

Suggested citation: Ruis SJ, Burr C, Blanco-Canqui H, et al. Corn residue baling and grazing impacts on corn yield under irrigated conservation tillage systems. Agronomy Journal. 2021; 11pp. https://doi.org/10.1002/agj2.20642 


\begin{abstract}
Crop residue grazing or baling is common in the western Corn Belt. However, its impacts on subsequent crop yields under different irrigation levels and tillage systems are unclear. We investigated the impacts of corn (Zea mays L.) residue baling and cattle grazing on soil compaction, water content, and corn yield under full and limited irrigated no-till in Nebraska during three years. In Years 2 and 3, an additional tillage treatment (strip till) was implemented to evaluate its effects on grain yield under the above treatments. Residue removal effects on compaction and water content did not vary with irrigation level. Grazing (3.68 animal units ha ${ }^{-1}$ ) minimally impacted compaction and soil profile water content compared to no removal. Baling increased cone index by $34-53 \%$ in the o-to-12.5- $\mathrm{cm}$ depth and decreased water content by $6 \mathrm{~cm}$ compared to no removal. Residue removal effects on yield did not depend on irrigation. Residue removal impacts depended on tillage in Year 3 only. Full irrigation increased corn yields up to $11 \%$ compared to limited irrigation. Strip till increased yield by 11\% compared to no-till in Year 2 only. Baling and grazing had no effect on corn yield in Year 1, but baling and grazing increased yield by $9 \%$ compared to no removal in Year 2 , likely due to lower water content. In Year 3 , grazing and baling increased yield by $9 \%$ under no-till but not strip till. Overall, grazing had minimal impacts while baling increased yield and compaction and decreased water content with few variations due to irrigation or tillage.
\end{abstract}

Abbreviations: AUM, animal unit month

\title{
Core Ideas
}

- Corn residue removal effects on compaction were small and below threshold to restrict root growth.

- Baling, unlike grazing, reduced soil water content in 1 of 2 yr compared to no removal.

- Baling and grazing increased corn yield in 2 of 3 yr.

- Limited irrigation reduced yield compared to full while strip till increased yield compared to no-till.

- Residue removal effects rarely varied with irrigation or tillage.

\section{Introduction}

Baling and grazing corn residues from the approximately 37 million hectares planted to corn (Zea mays L.) in the United States (USDANASS, 2017) are important to meet the need for animal feed and biofuel feedstocks. Corn residues are important feedstocks as pastureland shortages increase (Liebig et al., 2017). However, the amount of 
corn residue baled and grazed varies by region. For example, in the western Corn Belt, including Nebraska, Kansas, and Colorado, >20\% of corn residues are utilized for livestock and biofuel (Schmer et al., 2017). The level of utilization drops to $5-10 \%$ in the Midwest Corn Belt and below 5\% in the eastern Corn Belt (Schmer et al., 2017). The higher utilization of corn residues in the Midwest and particularly in the western Corn Belt is due to the increasing number of cattle in these locations. Across the United States, the cattle population is approximately 90 million (USDA-NASS, 2012), with about 11.7 million of those cattle grazing corn residues in 2010 (Schmer et al., 2017). Note that corn residue grazing is more common than baling (Ruis et al., 2018). For example, in Nebraska around 1.9 million hectares are grazed and 48,00o ha baled (Schmer et al., 2017). Across a four-state area with large beef cattle industry, including Nebraska, South Dakota, North Dakota, and Kansas, corn residues have a value of about US\$74.6 million (Redfearn et al., 2019). While corn residues have high value potential, questions exist regarding the impact of corn residue grazing and baling on subsequent crop yields. Does the potential impact of corn residue grazing and baling depend on irrigation level or tillage system? Two ways in which grazing and baling may adversely affect crop yields are cattle and machine traffic-induced compaction and reduction in soil water by removing the mulching effect that residues can provide.

Corn residue removal effects on corn grain yield and related properties of compaction and water content can depend on the amount of residue removed, animal stocking rate, and soil conditions during grazing. For example, in Nebraska, Shaver et al. (2018) found heavy grazing (o.8 animal unit month [AUM] ha ${ }^{-1}$ ) increased surface compaction by 1.7 times compared to no removal and light grazing ( 0.4 AUM ha-1), while baling did not affect compaction compared to no removal or heavy grazing. Despite the increased compaction with heavy grazing, there was no effect on corn grain yield. Similarly, Rakkar et al. (2017) reported light to moderate fall grazing (4.4 to 6.2 $\mathrm{AUM} \mathrm{ha}^{-1}$ ) had no effect on surface soil compaction while heavy grazing in spring (9.3 to 13 AUM ha ${ }^{-1}$ ) increased surface compaction by 3.4 times compared to no grazing in another study in Nebraska. Two studies across seven sites in Nebraska and a global review showed crop residue grazing did not affect subsequent crop yield (Rakkar et al., 2018; Stalker 
et al., 2015; Ulmer et al., 2018), regardless of whether the site was rainfed or irrigated (Rakkar et al., 2018).

As baling and grazing of corn residues become more common in the Great Plains, and as water usage for agriculture becomes more regulated, deficit irrigation levels may be needed to preserve groundwater resources. Studies comparing residue removal effects on compaction, water content, and crop yield under different irrigation levels are few. One of the previous studies investigating the impacts of residue removal in irrigated and rainfed sites in Kansas reported high rates of residue removal increased corn yield by $36 \%$ in 1 of $3 \mathrm{yr}$ at the irrigated site and by $25 \%$ in 2 of 3 yr at the rainfed site (Kenney et al., 2015). By contrast, in Nebraska, Ruis et al. (2017) reported corn residue removal had no effect on grain yield at a rainfed site in $3 \mathrm{yr}$, but at the irrigated site corn residue removal increased grain yield in 1 of $3 \mathrm{yr}$.

Previous studies often measured water content for shallow soil depths (up to $20 \mathrm{~cm}$ ) or at one measurement point in spring (Clark et al., 2004; Kenney et al., 2015; Rakkar et al., 2019; Ruis et al., 2017). One study that evaluated water content for the entire profile in Colorado showed residue removal reduced water content at planting for the 1.8-m depth and reduced overall precipitation storage efficiency (Schneekloth et al., 2020). Another study that evaluated soil water for the o-to-46-cm depth suggested grazing corn residues may tend to reduce soil water content (Tracy \& Zhang, 2008).

Studies comparing the effects of residue removal on corn yield under no-till and other conservation tillage methods such as strip till are scant. However, there are studies comparing residue removal effects on yield under tilled and no-till systems. For example, two studies in Nebraska and Kansas showed high rates of residue baling may increase corn yield under no-till, but not under conventional tillage (Kenney et al., 2015; Schmer et al., 2014). However, in Iowa, grain yield response to residue removal did not differ by tillage system (Sawyer et al., 2017). None of these studies directly compared residue removal impacts on soil water, compaction, and yield under no-till and strip till, the latter of which is a method that could utilize many of the benefits of both tillage and no-till.

Understanding the interactive effects of residue removal combined with other management strategies, such as irrigation, on soil-water 
content, compaction, and crop yield are critical given the increasing utilization of corn residues, increasing water restrictions, and depletion of groundwater resources but little research exists on these interactions. We investigated the impacts of corn residue baling and cattle grazing on soil compaction, water content, and corn yield under full and limited irrigated no-till in Nebraska. In Years 2 and 3, an additional tillage treatment (strip till)was implemented to evaluate its effects on grain yield under the above treatments.

\section{Materials and methods}

\subsection{Description of the experimental site, treatments, and management}

To achieve our objective, we established an experiment of corn residue removal in fall 2013 at the Bayer Crop Science, Water Utilization Learning Center $\left(40.886^{\circ} \mathrm{N}, 100.163^{\circ} \mathrm{W} ; 783\right.$ masl) near Gothenburg, NE. Treatments were no removal and corn residue removal by baling or grazing under no-till or strip till and full or limited irrigation levels. The location receives about $600 \mathrm{~mm}$ of precipitation annually and has a mean annual temperature of $10.2{ }^{\circ} \mathrm{C}$. Figure 1 reports data on air temperature and precipitation for the duration of the experiment. The soil was a Hord silt loam (fine-silty, mixed, superactive, mesic $\mathrm{Cu}$ mulic Haplustoll) with $<1 \%$ slope.

The experimental design was a split-strip randomized complete block with five replications. The main plot was corn residue removal treatments of no removal, residue grazing, and residue baling. The subplots were the two irrigation treatments (full and limited) which were established in strips at 90 degrees to the row direction following the linear irrigation system. In Year 1, the only tillage system was notill. However, in Year 2, we imposed sub-subplots of tillage (no-till and strip till) in the same direction of the corn rows in a split-strip fashion. The size of each plot was 3.33 by $20 \mathrm{~m}$ and treatments remained in the same plot area each year.

The irrigation treatments were applied by a linear move sprinkler system and scheduled based on a WaterMark granular matrix sensor (Irrometer Co., Inc., Riverside, CA). The full irrigation treatment was 

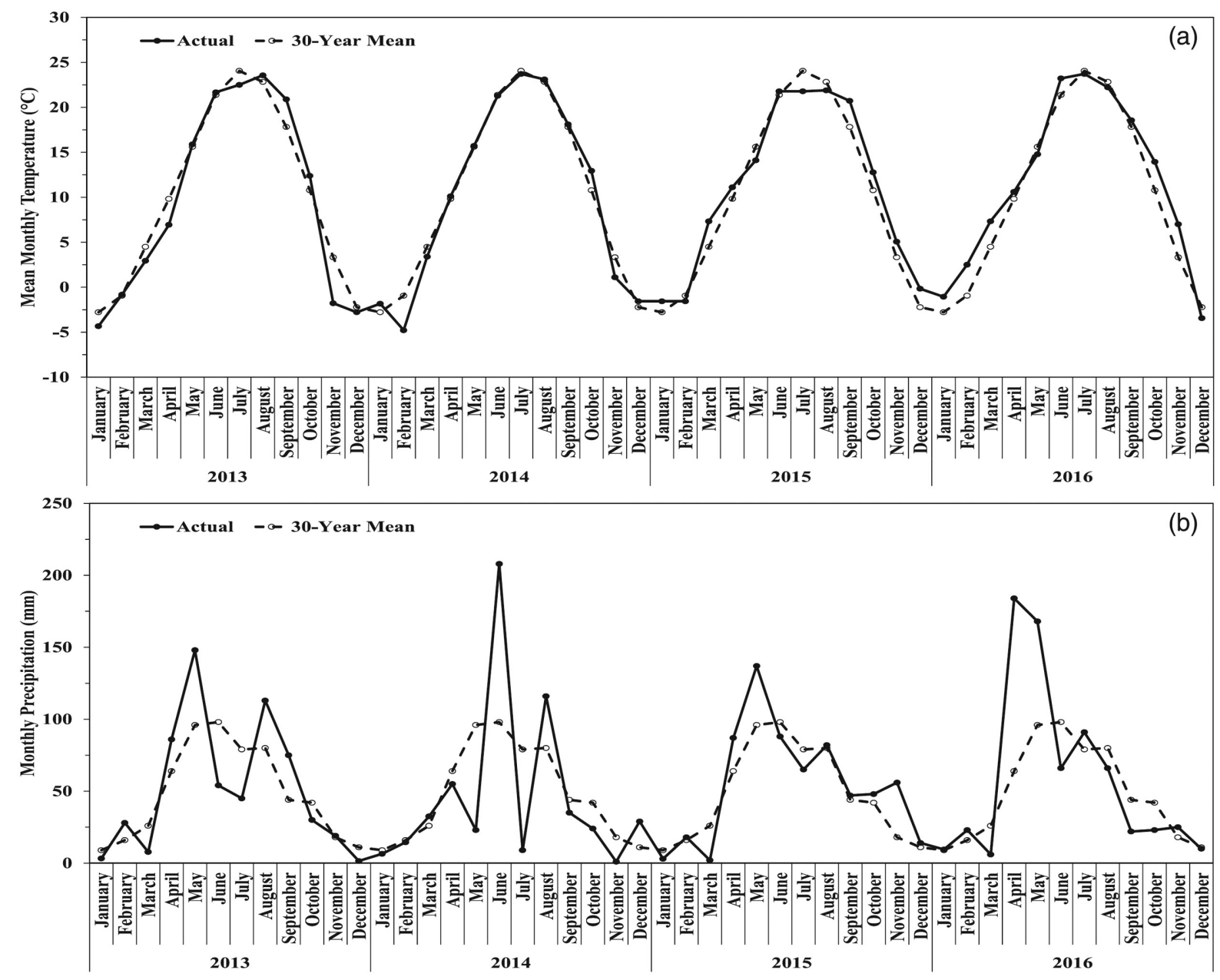

Figure 1 Actual and 30-yr (a) mean temperature and (b) precipitation for the experiment site near Gothenburg, NE

scheduled using WaterMark Soil Moisture Sensors placed in replication one of the no removal treatment. The limited irrigation treatment was targeted to apply 5-10 cm less irrigation than full. These irrigation levels were selected to understand if residue removal by baling or grazing differently affect water content, compaction, and crop yield when irrigation is applied at full or reduced rates. The reduced rate may reflect future scenarios where irrigation application rates may be limited. Rainfall during the grain-fill period (August-September) allowed for irrigation differences of $1.3 \mathrm{~cm}$ in 2014, $2.5 \mathrm{~cm}$ in 2015, and $5 \mathrm{~cm}$ in 2016. No-till plots were left undisturbed while strip-till plots were tilled in strips $25 \mathrm{~cm}$ wide and $20 \mathrm{~cm}$ deep in April each year, 1 
mo before planting. Corn was planted in early May at a rate of 85,000 plants ha ${ }^{-1}$ and fertilized at rates of $224 \mathrm{~kg} \mathrm{ha}^{-1}$ for $\mathrm{N}$ and $67 \mathrm{~kg} \mathrm{ha}^{-1}$ for $\mathrm{P}_{2} \mathrm{O}_{5}$ each year. Corn harvest occurred in October.

Corn stalks were cut, wind-rowed, and baled between late October and early March for the baled plots. Cattle grazed corn at 3.68 animal units ha ${ }^{-1}$ for about $5 \mathrm{~d}$ during winter ( $1 \mathrm{~d}$ per replication) for the grazed plots. Cattle grazed corn 16-21 February in 2014, 7-12 December in 2014, and 21- 26 December in 2015. The stocking density was based on the University of Nebraska Corn Stalk Grazing Calculator, which gives a stocking rate for a given crop yield (Stockton \& Wilson, 2013). Baling removed about $66 \%$ of residues while grazing removed about $24 \%$ of residues (Ruis et al., 2018).

\subsection{Assessment of compaction, water content, and corn yield}

We assessed compaction as cone index at five locations in each plot for the $0-$ to-27.5- $\mathrm{cm}$ soil depth at $2.5-\mathrm{cm}$ intervals using a Spectrum Field Scout SC90o penetrometer with 0.20- cm tip (Spectrum Technologies, Inc.; Lowery \& Morrison, 2002). The penetrometer had a sonar depth sensor, allowing us to collect data at each $2.5-\mathrm{cm}$ depth interval for the o-to-27.5-cm depth. Cone index data were only collected in the no-till plots because strip till would potentially alleviate any surface compaction due to baling or hoof traffic. Measurement occurred in spring on 9 Apr. 2014, 31 Mar. 2015, and 28 Mar. 2016. Cone index is often correlated with differences in water content and adjustments to common water content may be required (Blanco-Canqui et al., 2005; Busscher et al., 1997). However, we assumed water content was uniform at time of sampling cone index in spring because the site received sufficient precipitation (Figure 1) to fill the soil profile in winter and early spring. In the summer and fall months when irrigation treatments were imposed, water content was assumed to differ.

Soil water content was assessed using a CPN 503DR neutron moisture meter (InstroTek) in Years 2 and 3 of the study (2015 and 2016). Neutron access tubes were installed in three of the five replications for the irrigation and residue removal treatments. Readings were collected on 8 July, 3 Aug., 20 Aug., 9 Sept., and 25 Sept. 2015 and 28 June, 12 July, 2 Aug., 17 Aug., 2 Sept., 19 Sept., and 18 Oct. in 2016. At the time of readings, the neutron moisture meter was centered at 15 , 
46, 76, 107, and $137 \mathrm{~cm}$ below the soil surface. The neutron moisture meter was thermogravimetrically calibrated for the site with a resulting $R^{2}=.96$ following Blake and Hartge (1986). Neutron counts were converted to volumetric water content and then to soil water storage in millimeters. The sum of water storage from all depths was the water content for the soil profile.

Corn grain yield was determined in October of each year from the center two rows of each plot using a New Holland TR88 Combine with a Harvest Master high capacity grain gauge. Yield from the two row area was then scaled up to $\mathrm{Mg} \mathrm{ha}{ }^{-1}$. Corn residue amount $\left(\mathrm{Mg} \mathrm{ha}^{-1}\right)$ was assessed in spring for two $0.5 \mathrm{~m}^{2}$ quadrats per plot. All residues within the quadrats were clipped, collected, dried, and weighed and data reported by Ruis et al. (2018).

\subsection{Statistical analysis}

Data for yield were analyzed by ANOVA using the PROC GLIMMIX procedure in SAS 9.4 (SAS, 2020). Because 2014 did not include all treatments, the PROC GLIMMIX procedure for that year was conducted separately. For 2014, data was analyzed with irrigation and residue removal as fixed effects while replication was considered random. However, for the Years 2 and 3 (2015 and 2016), the PROC GLIMMIX procedure was run by year with fixed effects of residue removal, tillage, and irrigation; the replication was considered random. Data for cone index were analyzed using the PROC GLIMMIX procedure by year and depth with residue removal treatment as the fixed effects. Using the same model, the PROC GLM procedure was also used for cone index to obtain the LSD values for graphing purposes. Soil water storage was assessed using the GLIMMIX procedure for each date and depth interval and the full soil profile. Differences among treatments were considered significant at $p<.05$.

\section{Results}

\subsection{Compaction and soil water}

Cone index, an indicator of compaction, was assessed under both irrigation levels (full and limited) under no-till only as indicated earlier. 

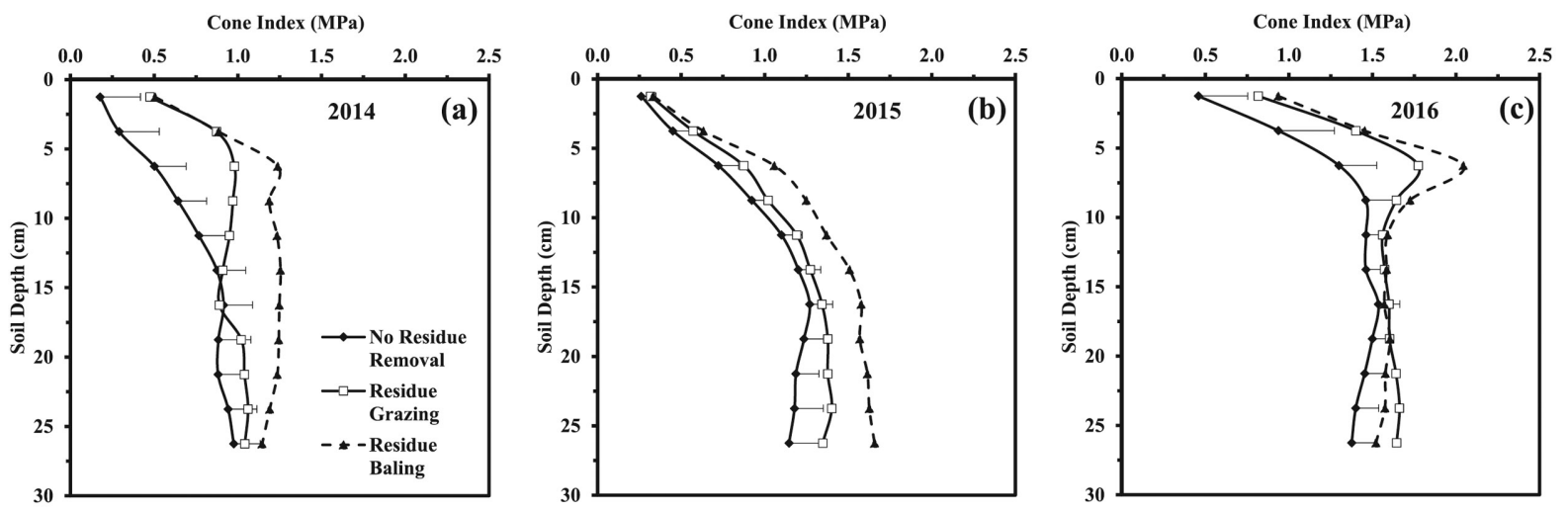

Figure 2 Influence of corn residue removal on cone index by soil depth in (a) 2014, (b) 2015, and (c) 2016 for the experiment near Gothenburg, NE. Error bars are LSD values for comparison of treatments within a depth

Residue removal including baling (66\% residue removal) and grazing (24\% residue removal) affected cone index at most depths, but irrigation levels had no effect. Across irrigation levels, residue baling increased cone index by about $53 \%$ in $2014,34 \%$ in 2015 , and $38 \%$ in 2016 in the upper $12.5-\mathrm{cm}$ depth (Figure $2 \mathrm{a}-\mathrm{c}$ ). Below the $12.5-\mathrm{cm}$ depth, residue baling increased cone index in the Years 1 and 2 while grazing generally had no effect. In the Year 3 , below the $12.5-\mathrm{cm}$ depth, the impacts of residue removal on cone index were variable with intermediate depths showing no effect and deeper depths showing higher cone index values for baling and grazing compared to no removal.

Soil water content measurements were assessed in no-till only during the Years 2 and 3 (2015 and 2016) years. Residue removal and irrigation significantly affected soil water content, but the effects varied by year, measurement date, and soil depth. There was no interaction of residue removal and irrigation level for any measurement date or soil depth. In the Year 2, for the 15- and 107-cm depths, baling reduced water content in four of five measurement dates by an average of $1.13 \mathrm{~cm}$ in the $15-\mathrm{cm}$ depth (Table 1 ) and $1.57 \mathrm{~cm}$ in the 107$\mathrm{cm}$ depth (Table 1). Grazing had no effect on water content compared to no removal. Measurement depths of 46,76 , and $137 \mathrm{~cm}$ were generally unaffected by residue removal. Irrigation also significantly affected water content (Table 1), but generally only for the 15 - $\mathrm{cm}$ depth. At this depth, limited irrigation had about $1 \mathrm{~cm}$ lower soil water content than full irrigation on three of five measurement dates. In Year 3, 


\begin{tabular}{|c|c|c|c|c|c|c|c|}
\hline & 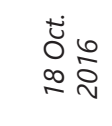 & 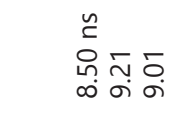 & 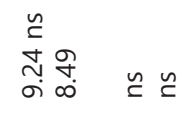 & 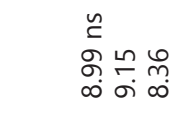 & 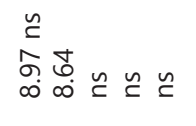 & 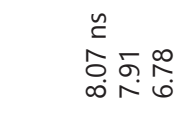 & 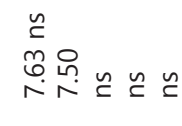 \\
\hline$\frac{\bar{c}}{0}$ & 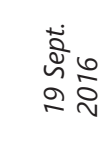 & 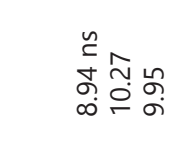 & 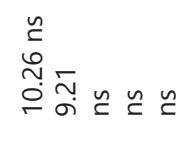 & 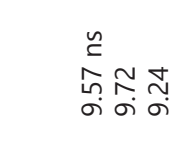 & 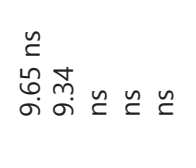 & 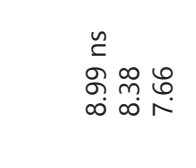 & 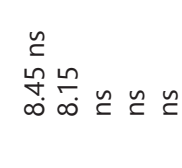 \\
\hline 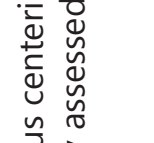 & 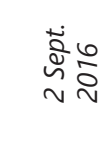 & 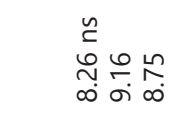 & 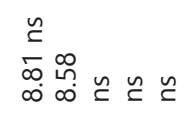 & 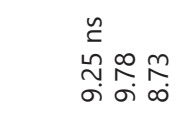 & 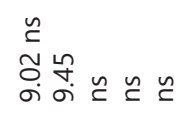 & 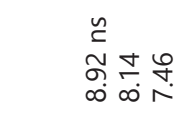 & 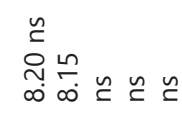 \\
\hline $\begin{array}{l}c \\
0 \\
n \\
0\end{array}$ & 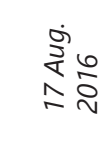 & 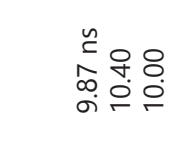 & 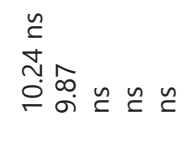 & 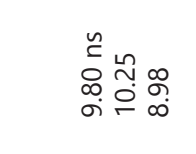 & 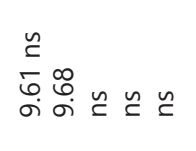 & 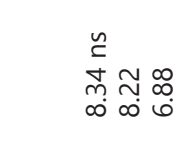 & 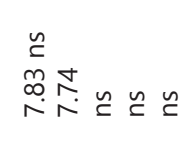 \\
\hline , & 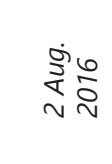 & 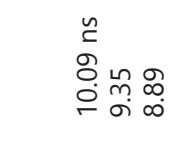 & 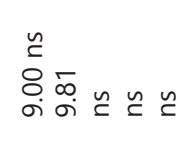 & 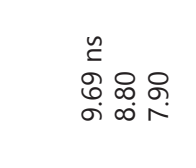 & 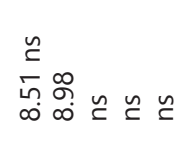 & 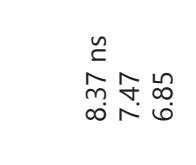 & 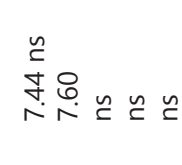 \\
\hline u & 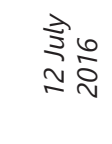 & 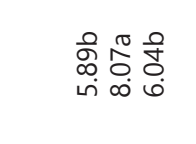 & 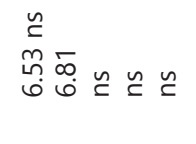 & 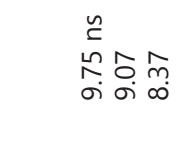 & 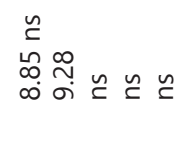 & 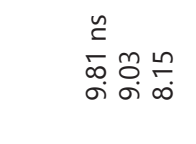 & 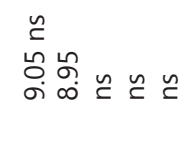 \\
\hline 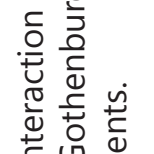 & 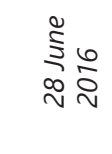 & 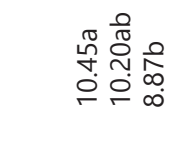 & 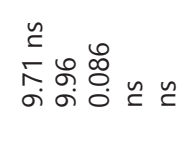 & 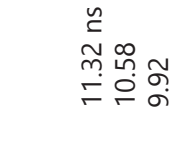 & 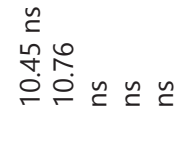 & 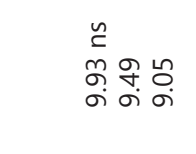 & 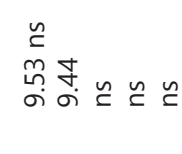 \\
\hline 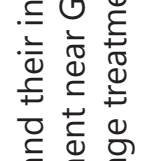 & 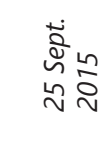 & 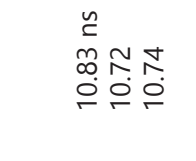 & 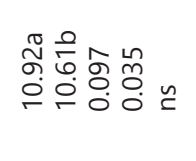 & 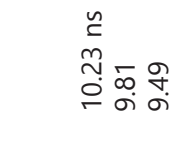 & 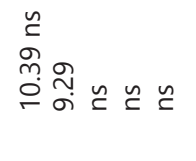 & 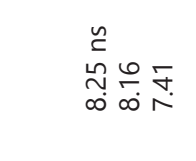 & 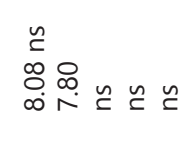 \\
\hline 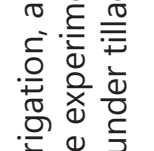 & 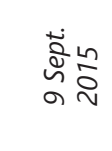 & 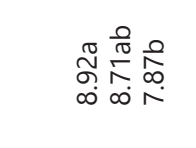 & 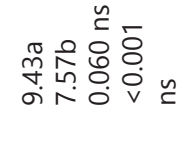 & 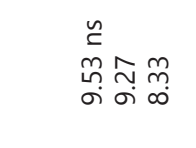 & 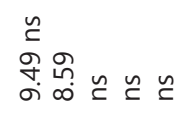 & 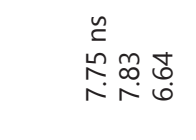 & 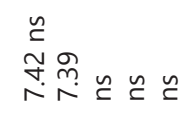 \\
\hline 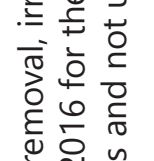 & 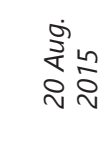 & 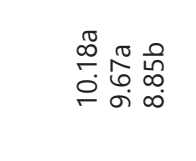 & 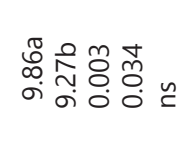 & 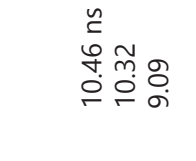 & 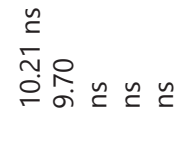 & 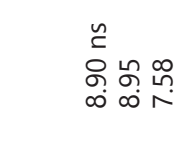 & 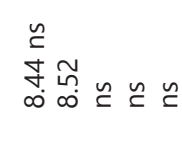 \\
\hline 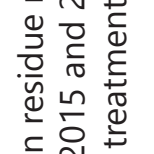 & $\underset{m}{\stackrel{3}{3}} \stackrel{n}{i}$ & 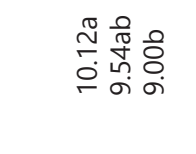 & 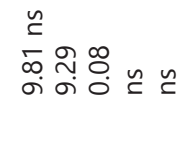 & 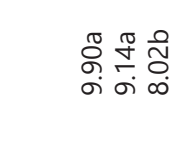 & 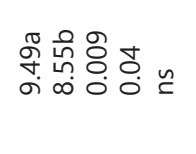 & $\begin{array}{l}n \\
\stackrel{n}{g} \\
\infty \\
\infty\end{array}$ & 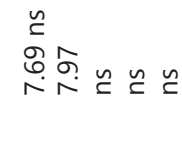 \\
\hline 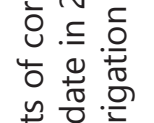 & 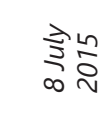 & 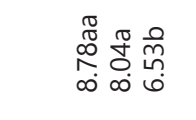 & 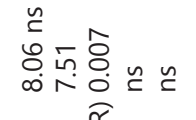 & 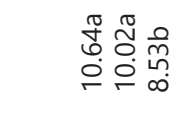 & 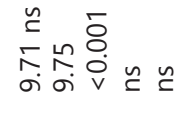 & 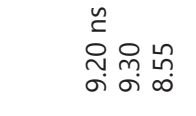 & 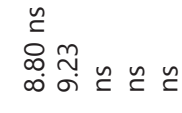 \\
\hline 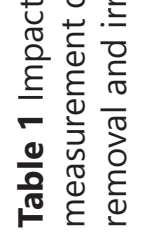 & 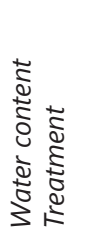 & 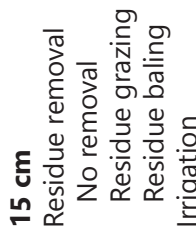 & 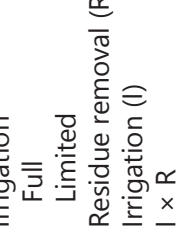 & 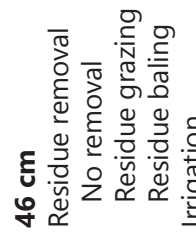 & d. & 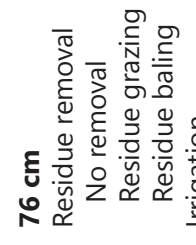 & 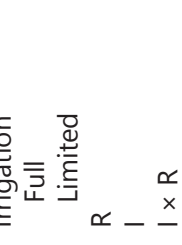 \\
\hline
\end{tabular}




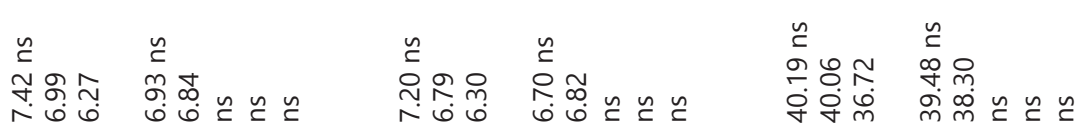

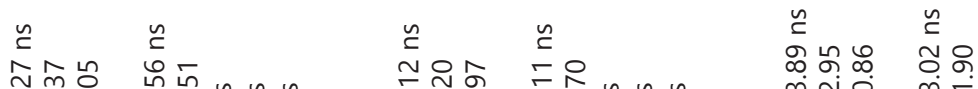

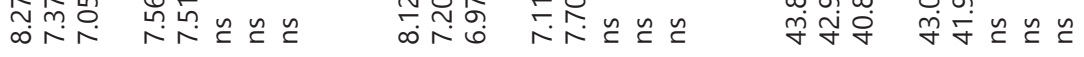

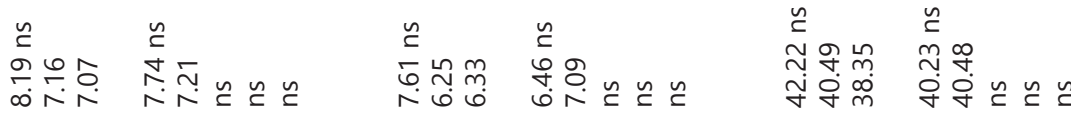

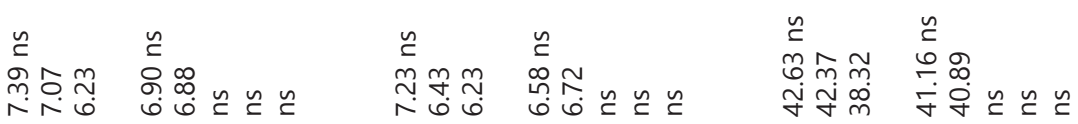

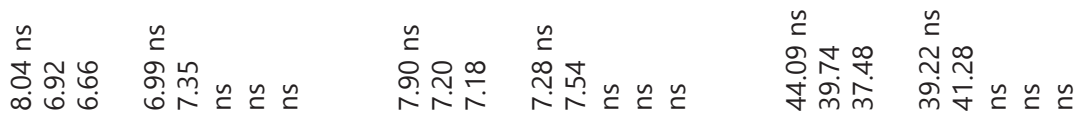

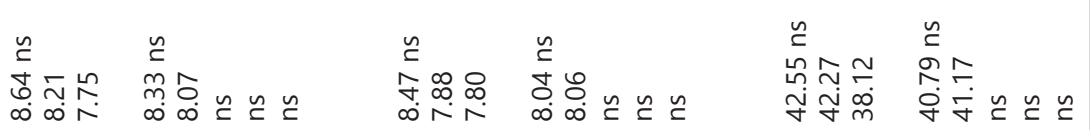

ปै

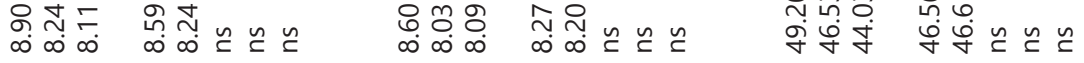

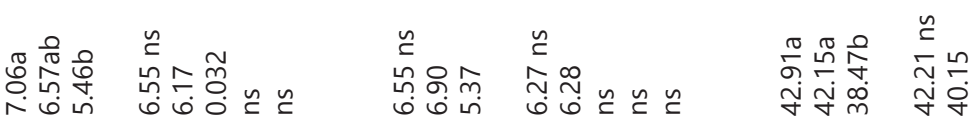

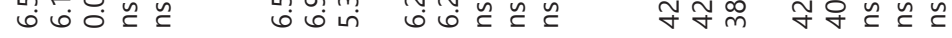

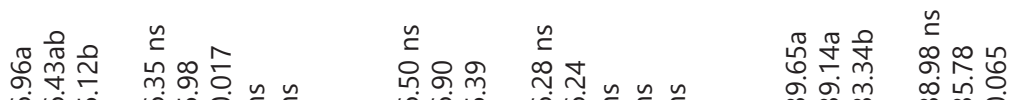

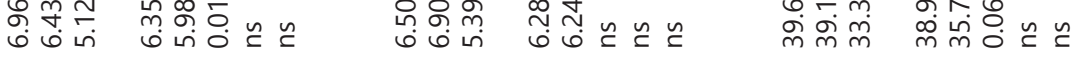

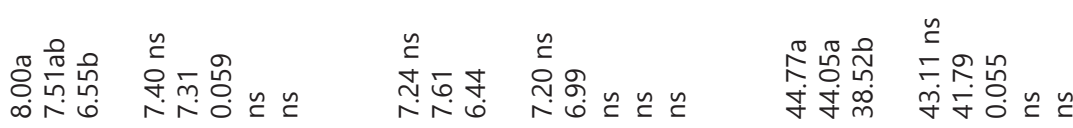

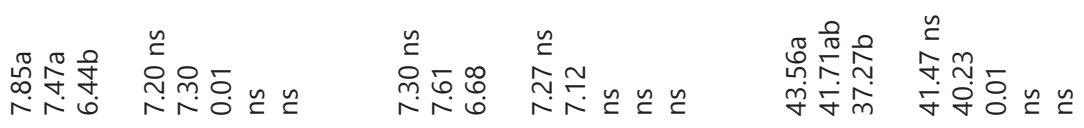

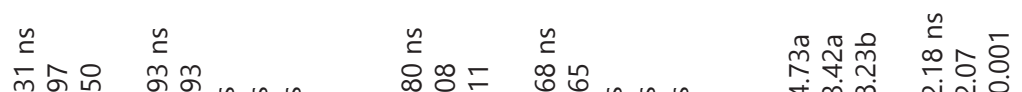

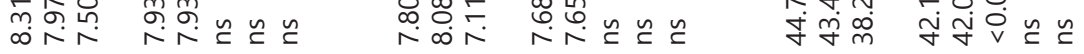

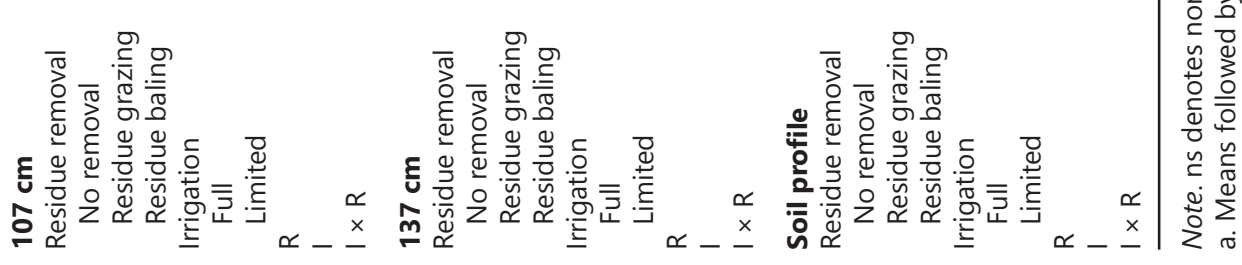


residue removal only affected water content for the $15-\mathrm{cm}$ depth on two of seven measurement dates. Irrigation level had no effect on soil water content in 2016 .

For the full soil profile, residue removal significantly affected soil water content, but not irrigation level (Table 1). As shown in Table 1, in Year 2, residue baling reduced soil profile water content by 5.96 $\mathrm{cm}$ compared to no removal while grazing had no effect, similar to the surface depth. In Year 3, residue removal did not affect soil water content, although residue baling tended to have lower water content than no removal.

\subsection{Corn yield}

In Year 1, residue removal and irrigation level had no effect on corn yield (Table 2). In Year 2, the main effects of residue removal, tillage, and irrigation affected corn yield. Residue baling increased corn yield by $11.5 \%$ and residue grazing by $7 \%$ compared to no removal. Strip till increased corn yield by about 11\% compared to no-till. Limited irrigation decreased corn yield by about 11\% compared to full irrigation. In Year 3, however, the main effects and the interaction of residue removal $\times$ tillage significantly affected corn grain yield. Limited irrigation decreased corn yield by about $2 \%$. Residue grazing and baling increased corn grain yield by $9 \%$ compared to no removal under no-till. However, residue grazing and baling did not affect corn yield compared to no removal under strip till. Strip till increased corn grain yield by $7 \%$ under no removal and residue grazing compared to the same treatments under no-till. Residue baling did not differ in its effect on corn grain yield between the two tillage systems.

\section{Discussion}

The increase in cone index with residue baling (66\% residue removal) in all 3 yr suggests that residue baling can slightly increase compaction risks under the conditions of this study (Figure 2). However, cone index was not above the $2 \mathrm{MPa}$ suggested to limit plant growth (Lin et al., 2016; Unger \& Kaspar, 1994). Residue baling at low rates may or may not have similar effects on compaction compared with high 
Table 2 Corn residue removal, irrigation, and tillage impacts on corn yield across 3 yr for the experiment near Gothenburg, NE. Note that tillage was not implemented until Year 2 or 2015.

\begin{tabular}{|c|c|c|c|}
\hline \multirow[t]{2}{*}{ Treatment } & \multicolumn{3}{|l|}{ Yield } \\
\hline & 2014 & 2015 & 2016 \\
\hline \multicolumn{4}{|l|}{$\mathrm{Mg} \mathrm{ha}^{-1}$} \\
\hline Full & 11.9 ns & 12.6aa & $12.6 a$ \\
\hline Limited & 11.7 & $11.4 \mathrm{~b}$ & $12.3 b$ \\
\hline \multicolumn{4}{|l|}{ Tillage } \\
\hline No-till & na & $11.4 \mathrm{~b}$ & $12.2 b$ \\
\hline Strip till & na & $12.7 a$ & $12.6 a$ \\
\hline \multicolumn{4}{|l|}{ Residue removal } \\
\hline No removal & $11.7 \mathrm{~ns}$ & $11.3 b$ & $12.4 \mathrm{~b}$ \\
\hline Grazing & 11.7 & $12.1 \mathrm{a}$ & $12.5 b$ \\
\hline Baling & 11.9 & $12.6 a$ & $13.0 \mathrm{a}$ \\
\hline \multicolumn{4}{|c|}{ Residue removal $\times$ Tillage } \\
\hline \multicolumn{4}{|c|}{ No-till } \\
\hline No removal & & & $11.6 \mathrm{Bb}^{\mathrm{b}}$ \\
\hline Grazing & & & $12.4 \mathrm{Ab}$ \\
\hline Baling & & & 12.8Aa \\
\hline \multicolumn{4}{|l|}{ Strip till } \\
\hline No removal & & & 12.6ABa \\
\hline Grazing & & & 13.0Aa \\
\hline Baling & & & $12.4 \mathrm{Ba}$ \\
\hline \multicolumn{4}{|l|}{$p$ value } \\
\hline Residue removal (RM) & ns & ns & $<0.001$ \\
\hline Tillage (T) & & $<0.001$ & 0.003 \\
\hline Irrigation (I) & ns & 0.001 & 0.006 \\
\hline $\mathrm{RM} \times \mathrm{I}$ & ns & ns & \\
\hline $\mathrm{RM} \times \mathrm{T}$ & & ns & $<0.001$ \\
\hline $\mathrm{I} \times \mathrm{T}$ & & ns & ns \\
\hline $\mathrm{RM} \times \mathrm{I} \times \mathrm{T}$ & & ns & ns \\
\hline
\end{tabular}

Note. ns denotes nonsignificant.

a. Means followed by different lowercase letters within the same column and same tillage treatment are statistically different at $p<.05$.

b. Means followed by different uppercase letters within the same column and residue removal treatment are statistically different.

rates of baling depending on the site and amount of residue produced (Kenney et al., 2015). Unlike residue baling, residue grazing (24\% residue removal) only increased compaction in the Years 1 and 3 in the o-to-12.5-cm depth, suggesting that grazing may occasionally increase compaction under no-till management. Unlike no-till, which may show compaction increases in the short-term, strip till is expected to reduce soil compaction. While we did not assess cone index under strip till, a companion study for the same experiment indicated that strip till reduced soil bulk density (Ruis et al., 2018). 
Baling likely increased compaction due to a combination of machine traffic and reduced soil C stocks (Ruis et al., 2018). A companion study for the same experiment showed residue baling reduce soil $\mathrm{C}$ stocks by $2.16 \mathrm{Mg} \mathrm{ha}^{-1} \mathrm{yr}^{-1}$ compared to no removal and grazing (Ruis et al., 2018). Residue grazing probably increased compaction through hoof traffic and wet or unfrozen soil conditions during grazing. Cattle hoof traffic imparts $114 \mathrm{~kg}$ of pressure with each step (Rakkar et al., 2017), thus repeated traffic can increase compaction (Clark et al., 2004; Shaver et al., 2018). The extent of compaction depends on stocking rate and soil water content. For example, low stocking rates (0.4-0.8 animal unit equivalents ha-1 and 3.7 cows ha $^{-1}$ ) may increase compaction in some years, particularly on unfrozen, wet soils (Clark et al., 2004; Shaver et al., 2018). Another study with both fall and spring grazing at two different stocking rates showed that moderate stocking rates (4.4-6.2 AUM ha $\left.{ }^{-1}\right)$ in fall may not affect soil compaction, unlike high stocking rates (9.3-13 AUM ha-1) in spring on wet, unfrozen soils (Rakkar et al., 2018). Thus, the minimal impacts of grazing on compaction in our study are similar to previous work with similar stocking rates and fall grazing.

The reduction in water content due to limited irrigation in 1 of 2 yr (2015 and 2016) was likely due to rainfall patterns. The year in which limited irrigation reduced water content coincided with a year of lower than average rainfall in July (Figure 1). The reduction in water content with residue baling in both 2015 and 2016 (water content measured the Year 2 of study) and no effects of grazing (Table 1) suggest baling can consistently reduce soil water content during the grain-fill period unlike grazing (Figure 1). The reduction in soil water content due to baling was probably due to the loss of corn residue cover (Ruis et al., 2018), which increases evapotranspiration (Klocke et al., 2009).

The limited effects of grazing on water content were likely due to the low amount (24\%) of residue removed by grazing compared with baling (66\%) (Ruis et al., 2018). Our results on residue baling effects on water content near the soil surface are in line with others who reported that residue removal by baling typically reduces soil water content in the surface $5 \mathrm{~cm}$ (Kenney et al., 2015; Rakkar et al., 2019; Shaver et al., 2018), unlike grazing (Rakkar et al., 2019; Shaver et al., 2018). These studies (Kenney et al., 2015; Rakkar et al., 2019; Shaver 
et al., 2018) highlight the negative impacts of residue baling and the minimal impacts of grazing on water content in the surface soil. Note that baling at low rates $(<50 \%)$ may have minimal effects on surface $(0-5 \mathrm{~cm})$ soil water content (Kenney et al., 2015). Unlike the previous studies, which only assessed water content in the surface depth, our study also shows that residue baling, but not grazing, can reduce water content in the full soil profile.

The reduction in corn yield by $6 \%$ in 2 of 3 yr under limited irrigation suggests that even small $(1.3-5 \mathrm{~cm})$ reductions in irrigation during the grain-fill period can impart risk of yield losses in the climate of this study. Studies in the region demonstrated similar reductions in yield with reduced irrigation (Klocke et al., 2011; Payero et al, 2006; Rudnick et al., 2016) where the greater the deficit in irrigation, the greater the potential reduction in yield (Klocke et al., 2011; Payero et al., 2006). For example, Payero et al. (2006) reported that replacing about one-third of evapotranspiration instead of about 50\% replacement reduced corn grain yield by $19 \%$ in a dry year. Similarly, Klocke et al. (2011) reported applying $<70 \%$ of evapotranspiration losses reduced corn yield by $41 \%$.

Strip till increased corn yield compared to no-till in both years of tillage treatments, and improved yield of the control and grazing treatments under no-till, which suggests it could be an alternative to baling while achieving similar objectives. One of the objectives with tillage is increased spring soil warming, which can enhance corn establishment compared to no-till (Vetsch \& Randall, 2002). Indeed, some previous studies comparing the effects between strip till and no-till on corn yield show increases of 4-6\% with strip till in Minnesota, Wisconsin, and Illinois (Fernandez et al., 2012; Potratz et al., 2020; Vetsch \& Randall, 2002). However, the yield benefit from strip till may not be universal, indicating that it may not be beneficial at every site (Viswakumar et al., 2008). Strip till could be paired with grazing without negative impacts to corn yield (Table 2) which means the corn residue could still be used as a feedstock. As shown in another study in the region, no-till, when paired with grazing may have no effects on crop yields (Stalker et al., 2015). However, the negative impacts of strip till on soil properties and long-term soil fertility must be considered. For example, as shown in a companion study, strip till reduced soil organic C stocks, increased water erosion potential, and reduced 
microbial activity compared to no-till (Ruis et al., 2018). Thus, while strip till may increase crop yield, its use must be balanced with the negative impacts to soils.

\section{Conclusions}

This study investigating the effects of corn residue removal under different, irrigation levels and tillage systems on soil compaction, soil water content, and corn yield in the western Corn Belt showed residue removal effects were generally independent of irrigation level and tillage system. Corn residue baling (66\% residue removal) slightly increased compaction, decreased water content in the soil profile, but increased corn yield, which suggests that during drought periods, irrigation may be needed earlier in the season and at greater frequency due to lower water storage. Residue grazing (24\% residue removal), however, had variable effects on compaction, water content, and corn yield. Strip tillage appeared to reduce residue removal effects on corn yield relative to no-till likely due possibly to tillage-induced soil mixing. Irrigation level did not generally interact with tillage or residue removal to affect compaction and water content. Limited irrigation reduced corn yield compared to full irrigation. However, grazing may be an alternative to baling because it has minimal impacts to compaction, water content, and crop yields. Overall, the impacts of residue removal practices of baling and grazing did not depend on irrigation level or tillage system, rather each study factor typically had independent impacts on soil compaction, water content, and crop yields.

Conflict of interest The authors declare no conflict of interest.

Bayer is a registered trademark of Bayer Group. (C)2020 Bayer Group. All rights reserved. 


\section{References}

Blake, G. R., \& Hartge, K. H. (1986). Bulk density. In A. Klute (Ed.), Methods of soil analysis. Part 1: Physical and mineralogical methods (pp. 363-375). Madison, WI: ASA and SSSA.

Blanco-Canqui, H., Lal, R., Owens, L. B., Post, W. B., \& Izaurralde, R. C. (2005). Strength properties and organic carbon of soils in the North Appalachian Region. Soil Science Society of America Journal, 69, 663-673. https://doi. org/10.2136/sssaj2004.0254

Busscher, W. J., Bauer, P. J., Camp, C. R., \& Sojka, R. E. (1997). Correction of cone index for soil water content differences in a coastal plain soil. Soil and Tillage Research, 43, 205-217. https://doi.org/10.1016/S0167-1987(97)00015-9

Clark, J. T., Russell, J. R., Karlen, D. L., Singleton, P. L., Busby, W. D., \& Peterson, B. C. (2004). Soil surface property and soybean yield response to corn stove grazing. Agronomy Journal, 96, 1364-1371. https://doi.org/10.2134/ agronj2004.1364

Fernandez, F. G., \& White, C. (2012). No-till and strip-till corn production with broadcast and subsurface-band phosphorus and potassium. Agronomy Journal, 104, 996-1005. https://doi.org/10.2134/agronj2012.0064

Kenney, I., Blanco-Canqui, H., Presley, D. R., Rice, C. W., Janssen, K., \& Olson, B. (2015). Soil and crop response to stover removal from rainfed and irrigated corn. GCB Bioenergy, 7(2), 219-230. https://doi.org/10.1111/gcbb.12128

Klocke, N. L., Currie, R. S., \& Aiken, R. M. (2009). Soil water evaporation and crop residues. Transactions of the ASABE, 52, 103-110. https://doi. org/10.13031/2013.25951

Klocke, N. L., Currie, R. S., Tomsicek, D. J., \& Koehn, J. (2011). Corn yield response to deficit irrigation. Transactions of the ASABE, 54, 931-940. https://doi. org/10.13031/2013.37118

Liebig, M. A., Ryschawy, J., Kronberg, S. L., Archer, D. W., Scholljegerdes, E. J., Hendrickson, J. R., \& Tanaka, D. L. (2017). Integrated crop-livestock system effects on soil N, P, and pH in a semiarid region. Geoderma, 289, 178-184.

Lin, L., He, Y., \& Chen, J. (2016). The influence of soil drying- and tillageinduced penetration resistance on maize root growth in a clayey soil. Journal of Integrative Agriculture, 15, 1112-1120. https://doi.org/10.1016/ S2095-3119(15)61204-7

Lowery, B., \& Morrison, J. E. (2002). Soil penetrometers and penetrability. In J. H. Dane \& G. C. Topp (Eds.), Methods of soil analysis. Part 4: Physical methods (pp. 363-388). Madison, WI: SSSA.

Payero, J. O., Melvin, S. R., Irmak, S., \& Tarkalson, D. (2006). Yield response of corn to deficit irrigation in aa semiarid climate. Agricultural Water Management, 84, 101-112. https://doi.org/10.1016/j.agwat.2006.01.009

Potratz, D. J., Mourtzinis, S., Gaska, J., Lauer, J., Arriaga, F. J., \& Conley, S. P. (2020). Strip-till, other management strategies, and their interactive effects on corn grain and soybean seed yield. Agronomy Journal, 112, 72-80. https://doi. org/10.1002/agj2.20067 
Rakkar, M. K., \& Blanco-Canqui, H. (2018). Grazing of crop residues: Impacts on soils and crop production. Agriculture Ecosystems and Environment, 258, 7190. https://doi.org/10.1016/j.agee.2017.11.018

Rakkar, M. K., Blanco-Canqui, H., Drijber, R. A., Drewnoski, M. E., MacDonald, J. C., \& Klopfenstein, T. (2017). Impacts of cattle grazing of corn residues on soil properties after 16 years. Soil Science Society of America Journal, 81, 414-424. https://doi.org/10.2136/sssaj2016.07.0227

Rakkar, M. K., Blanco-Canqui, H., Rasby, R. J., Ulmer, K., Cox- O’Neill, J., Drewnoski, M. E., . . MacDonald, J. C. (2019). Grazing crop residues has less impact in the short-term on soil properties than baling in the Central Great Plains. Agronomy Journal, 110, 109-121. https://doi.org/10.2134/ agronj2018.03.0224

Redfearn, D., Parsons, J., Drewnoski, M., Schmer, M., Mitchell, R., MacDonald, J., ... Smart, A. (2019). Assessing the value of grazed corn residue for crop and cattle producers. Agricultural \& Environmental Letters, 4, 180066. https://doi. org/10.2134/ael2018.12.0066

Rudnick, D., Irmak, S., Ferguson, R., Shaver, T., Djaman, K., . . van Donk, S.(2016). Economic return versus crop water productivity of maize for various nitrogen rates under full irrigation, limited irrigation, and rainfed settings in south central Nebraska. Journal of Irrigation and Drainage Engineering, 142, 04016017. https://doi.org/10.1061/(ASCE)IR.1943-4774.0001023

Ruis, S., Blanco-Canqui, H., Burr, C., Olson, B., Reiman, M., Rudnick, D., . . . Shaver, T. (2018). How does corn residue baling and grazing under different irrigation and tillage levels affect soil properties? Soil Science Society of America Journal, 82, 202-213. https://doi.org/10.2136/sssaj2017.05.0177

Ruis, S., Blanco-Canqui, H., Jasa, P., Ferguson, R., \& Slater, G. (2017). Can cover crop use allow increased levels of corn residue removal for biofuel in irrigated and rainfed systems? BioEnergy Research, 10, 992-1004. https://doi. org/10.1007/s12155-017-9858-z

SAS Institute. (2020). SAS 9.4 documentation and help. Cary, NC: SAS Institute. http://go.documentation.sas.com (accessed 28 May 2020).

Sawyer, J. E., Woli, K. P., Barker, D. W., \& Pantoja, J. L. (2017). Stover removal impact on corn plant biomass, nitrogen, and use efficiency. Agronomy Journal, 109, 802-810. https://doi.org/10.2134/agronj2016.11.0672

Schmer, M. R., Brown, R. M., Jin, V. L., Mitchell, R. B., \& Redfearn, D. D. (2017). Corn residue use by livestock in the United States. Agricultural \& Environmental Letters, 2, 1-4. https://doi.org/10.2134/ael2016.10.0043

Schmer, M. R., Jin, V. L., Wienhold, B. J., Varvel, G. E., \& Follett, R. F. (2014). Tillage and residue management effects on soil carbon and nitrogen under irrigated continuous corn. Soil Science Society of America Journal, 78, 19871996. https://doi.org/10.2136/sssaj2014.04.0166

Schneekloth, J., Calderon, F., Nielsen, D., \& Fonte, S. J. (2020). Tillage and residue management effects on irrigated maize performance and water cycling in a semiarid cropping system of Eastern Colorado. Irrigation Science, 38, 547-557. https://doi.org/10.1007/s00271-020-00702-2 
Shaver, T. M., Stalker, L. A., Blanco-Canqui, H., \& van Donk, S. J. (2018). Effects of 5 years of corn residue grazing and baling on nitrogen cycling, soil compaction, and wind erosion potential. Journal of Plant Nutrition, 41, 2425-2437. https:// doi.org/10.1080/01904167.2018.1510521

Stalker, L. A., Blanco-Canqui, H., Gigax, J. A., McGee, A. L., Shave, T. M., \& van Donk, S. J. (2015). Corn residue stocking rate affects cattle performance but not subsequent grain yield. Journal of Animal Science, 93, 4977-4983. https://doi. org/10.2527/jas.2015-9259

Stockton, M. C., \& Wilson, R. (2013). Corn stalk grazing calculator. University of Nebraska-Lincoln, Lincoln, NE. Retrieved from http://beef.unl.edu/learning/ cornstalkgrazingcalc.shtml Accessed 16 August 2017.

Tracy, B. F., \& Zhang, Y. (2008). Soil compaction, corn yield response, and soil nutrient pool dynamics within an integrated crop-livestock system in Illinois. Crop Science, 48, 1211-1218. https://doi.org/10.2135/cropsci2007.07.0390

Ulmer, K. M., Rasby, R. J., MacDonald, J. C., Blanco-Canqui, H., Rakkar, M. K., Cox, J. L., . . Drewnoski, M. E. (2018). Baling or grazing of corn residue does not reduce crop production in Central United States. Agronomy Journal, 110, 122-127.

Unger, P.W., \& Kaspar, T. C. (1994). Soil compaction and root growth- a review. Agronomy Journal, 86, 759-766. https://doi.org/10.2134/agronj1994.00021962 $008600050004 \mathrm{X}$

USDA-NASS. (2012). 2012 U.S. Summary and state data. USDA NASS. https:// www.nass.usda.gov (accessed 2 Mar 2017).

USDA-NASS. (2017). Statistics by subject. National statistics for corn. USDA-NASS. https://www.nass.usda.gov/Statistics_by_Subject (accessed 2 Mar 2017).

Vetsch, J. A., \& Randall, G. W. (2002). Corn production as affected by tillage system and starter fertilizer. Agronomy Journal, 94, 532-540. https://doi. org/10.2134/agronj2002.5320

Viswakumar, A., Mullen, R.W., Sudermeier, A., \& Dygert, C. E. (2008). Tillage and nitrogen application methodology impacts on corn grain yield. Journal of Plant Nutrition, 31, 1963-1974. https://doi.org/10.1080/01904160802403102 